苟

SSCL-Preprint-168

November 1992

Distribution Category: 414

M. J. Syphers

\title{
SSC Design Update
}

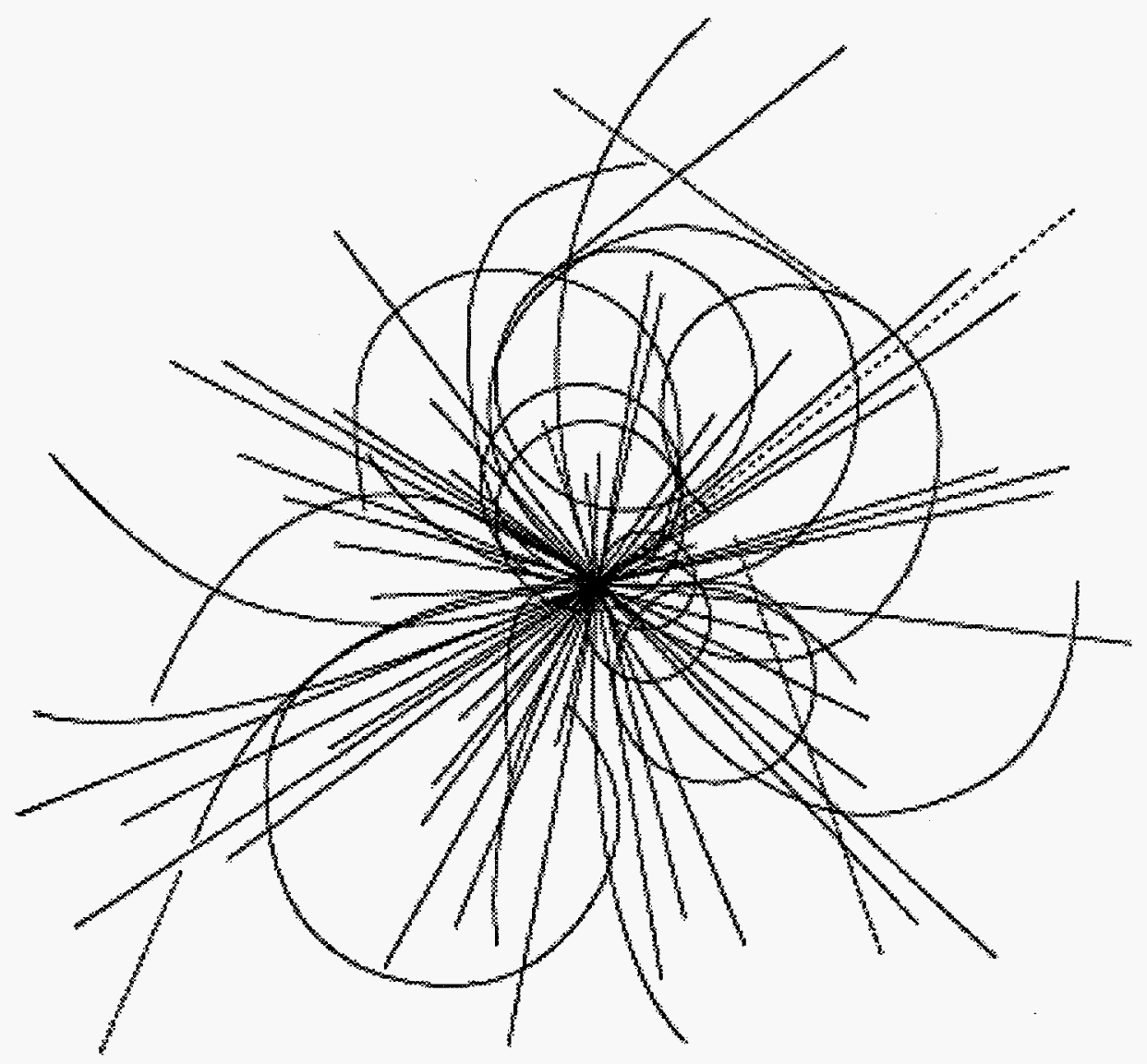

\section{Superconducting Super Collider Laboratory}

APPROVED FOR RELEASE OR PUBLICATION - O.R. PATENT dRROUP BY... E ......DATE. 42/Q5. 


\section{Disclaimer Notice}

This report was prepared as an account of work sponsored by an agency of the United States Government. Neither the United States Government or any agency thereof, nor any of their employees, makes any warranty, express or implied, or assumes any legal liability or responsibility for the accuracy, completeness, or usefulness of any information, apparatus, product, or process disciosed, or represents that its use would not infringe privately owned rights. Reference herein to any specitic commercial product, process, or service by trade name, trademark, manulacturer, or otherwise, does not necessarily constitute or imply its endorsement, recommendation, or favoring by the United States Government or any agency thereof. The views and opinions of authors expressed herein do not necessarily state or reflect those of the United States Government or any agency thereof. 


\title{
SSC Design Update
}

\author{
M. J. Syphers \\ Superconducting Super Collider Laboratory* \\ 2550 Beckleymeade Ave. \\ Dallas, TX 75237
}

November 1992

\section{DISCLAIMER}

This report was prepared as an account of work sponsored by an agency of the United States Government. Neither the United States Government nor any agency thereof, nor any of their employees, makes any warranty, express or implied, or assumes any legal liability or responsibility for the accuracy, completeness, or usefulness of any information, apparatus, product, or process disclosed, or represents that its use would not infringe privately owned rights. Reference herein to any specific commercial product, process, or service by trade name, trademark, manufacturer, or otherwise does not necessarily constitute or imply its endorsement, recommendation, or favoring by the United States Government or any agency thereof. The views and opinions of authors expressed herein do not necessarily state or reflect those of the United States Government or any agency thereof.

*Operated by the Universities Research Association, Inc., for the U.S. Department of Energy under Contract No. DE-AC35-89ER40486. 


\section{DISCLAIMER}

Portions of this document may be illegible in electronic image products. Images are produced from the best available original document. 


\title{
SSC DESIGN UPDATE
}

\author{
M. J. Syphers \\ SSC Laboratory* \\ 2550 Beckleymeade Ave. \\ Dallas, Texas 75237, USA
}

\begin{abstract}
Recent developments in the design and construction of the SSC are presented. Topics include status of the $20 \mathrm{TeV}$ Collider rings, including interaction regions, utility regions, and main arcs, plus some remarks on the injector accelerators. Remaining issues facing the design of the colliding beams synchrotron and its injectors are discussed.
\end{abstract}

\section{The Past 15 Months}

During the past 15 months since the Vancouver Meeting, many advances have been made at the SSC Laboratory, not the least of which has been the project's survival in Congress. The list of the laboratory's successes this past year includes the construction of a Magnet Development Laboratory; near completion of a Magnet Test Laboratory; construction of the Accelerator Systems String Test facility, and phase I of the first cryogenic refrigeration plant. Underground construction of main Collider facilities is well under way: 40 miles of the 53 mile tunnel is now under contract for construction. Four shafts to tunnel depth have been drilled, including. the first two magnet delivery shafts which will be used as starting points for the first two tunnel boring drives. While not yet assembled underground, the first two tunnel boring machines have arrived on site, and tunneling is expected to begin at these locations in January, 1993. In addition, construction began this past May on the linac tunnel and competitive bids were opened this month on the Low Energy Booster tunnel construction.

A major laboratory milestone was reached on August 14, 1992 with the successful powering of a complete half-cell, including a string of industrially produced Collider dipole magnets, to full excitation. This crucial test is discussed further

\footnotetext{
*Operated by the Universities Research Association, Inc., for the U.S. Department of Energy.
} 
elsewhere in these proceedings[1]. Further tests with this facility have begun.

\section{Design Update}

The basic design parameters of the SSC accelerators have not changed since they were reported last year at this meeting.[2] The content of this report will concentrate on the Collider design. Details of other design choices, in particular injector parameters, can be found elsewhere.[4]

\subsection{Collider Arcs}

The geometrical layout of the main Collider arcs has been finalized for some months now. In March, 1992, it was officially decided to go forward with a new design in which 26 dipole magnets are removed from each arc of the Collider to provide space for future uses. Such uses could include beam scrapers, beam dampers, correction magnets, polarization preserving devices (e.g., Siberian snakes), and other beam diagnostic devices. This change raised the field of the main bending magnets by $1.27 \%$, which can be compensated by a modest increase in refrigeration.

Advantage has already been taken of some of this space; $1 \mathrm{~m}$ long skew quadrupole correctors will now be placed at these locations relieving the need for $0.4 \mathrm{~m}$ skew quadrupoles in the middle of half cells. Early in the project when the injection energy was $1 \mathrm{TeV}$ and the dipole aperture was $4 \mathrm{~cm}$, mid-cell correctors of various types were required for proper beam performance. The last major corrector in these locations was the skew quadrupole. Now, with this function moved to the "missing dipole" locations, the $0.5 \mathrm{~m}$ mid-cell space can perhaps be moved to the main quadrupole or to the spool piece. This move is under consideration.

\subsection{West Utility Region}

One of the more complicated areas of the Collider is the West Utility straight section, where numerous facilities are located crucial to the operation of the accelerator. It is in this $1.35 \mathrm{~km}$ region where beam is injected from the High Energy Booster (HEB), RF systems are located for accelerating the beam, scrapers are located for cleaning beam halo, and beam is extracted toward the beam dump after a store or due to an abort. Systems for both the clockwise and counterclockwise traveling proton beams are located in this one straight section. Other functions will be performed here, such as special beam diagnostics and damping of beam oscillations (both transverse and longitudinal).

The optical properties of this region have been altered during the past year to improve many of the above operations. Ring-standard superconducting dipole magnets are now used to produce the necessary beam bump in the middle of the long straight section to reduce its length from $500 \mathrm{~m}$ to approximately $380 \mathrm{~m}$. The excess length could then be used to improve the injection optics as well as the placement of injection kickers. In addition, the maximum value of the amplitude function in this region was reduced by a factor of two, improving the aperture restrictions at injection. The number of special length quadrupoles was also minimized, in 


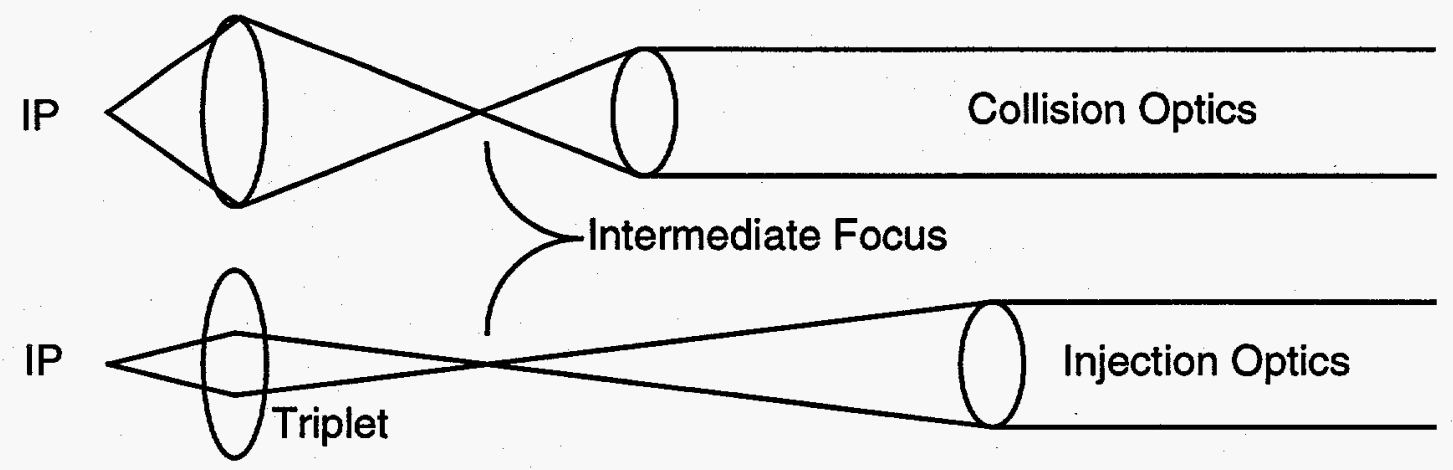

Figure 1: Principle of Interaction Region Optics.

coordination with the optical design of the interaction regions.

\subsection{Interaction Regions}

Much design work has taken place during the past year with regard to the interaction regions, in an effort to decide upon the required magnet development necessary to meet the needs of the IRs, and in order to be as flexible as possible for detector requirements as they unfold. The basic principle of the IR system is that of a telescope. The beam from the arc is brought to a fixed "intermediate" focus using a series of six individually powered quadrupoles. The fixed focal length triplet quadrupoles just in front of the interaction point then focus the beam to its final spot size.(See Figure 1.) Various values of $\beta^{*}$ are obtained by tuning the beam parameters at the intermediate focus using the six quadrupoles, essentially moving the focal plane of the secondary lens.

It was decided that the quadrupole magnets would be of $5 \mathrm{~cm}$ bore operating at approximately $193 \mathrm{~T} / \mathrm{m}$ gradients. With this aperture and field, it is felt that a maximum amplitude function of $\hat{\beta}=9 \mathrm{~km}$ is acceptable. This is the maximum produced for $\beta^{*}=0.5 \mathrm{~m}$ and with detector free space (IP to first quadrupole) of $L^{*}=$ $20 \mathrm{~m}$. Keeping $\hat{\beta}=9 \mathrm{~km}$ as a constraint, this optical system in principal can be used for various values of $L^{*}$ ranging from $20 \mathrm{~m}$ up to at least $90 \mathrm{~m}$ with a corresponding reduction in luminosity. In each instance, the triplet quadrupoles would need to have different lengths in order to regenerate the intermediate focus, but the remainder of the IR design would be unchanged. The system is also optimized in order to keep the maximum amplitude function throughout the region minimized for the injection optics; its maximum is similar to that in the utility region, under $700 \mathrm{~m}$.

If, at some later date, a larger aperture quadrupole with similar gradient as the present design could be produced and installed, then the tuning quadrupoles could be adjusted to produce lower $\beta^{*}$; for $L^{*}=20 \mathrm{~m}$, the present design can provide $\beta^{*}=0.25 \mathrm{~m}$. For this case, $\hat{\beta}$ increases to roughly $18 \mathrm{~km}$.

In addition, by increasing $L^{*}$, the same basic IR design can be used to replace the previous "medium beta" design of the SCDR.[3] This can reduce the number of types (i.e., lengths) of magnets necessary in the initial construction phase of the 
Table 1: Possible IR Configurations

\begin{tabular}{|c|c|c|c|c|c|c|}
\hline$L^{*}$ & $\beta^{*}(\mathrm{~m})$ & $\beta^{*}(\mathrm{~m})$ & Triplet & Quad & Lengths & \\
Inject. & Collision & QL1 & QL2 & QL3 & $\mathcal{L} / 10^{33}$ \\
\hline 20.5 & 7.0 & 0.5 & 15.6 & 11.9 & 13.2 & 1.00 \\
34.6 & 11.0 & 0.7 & 12.6 & 11.2 & 12.6 & 0.71 \\
56.9 & 23.0 & 1.1 & 10.3 & 10.3 & 11.9 & 0.54 \\
90.0 & 40.0 & 2.0 & 8.7 & 9.4 & 11.2 & 0.25 \\
\hline
\end{tabular}

project. At present, the two large low- $\beta$ detectors are to be located on the east side of the Collider, where their foundations will be in the Austin chalk. It is envisioned that smaller experimental halls will be located on the west campus. Table 1 shows possible configurations of the design with the effect on luminosity, assuming $5 \mathrm{~cm}$ quadrupoles $(\hat{\beta}=9 \mathrm{~km})$.

\section{Design Issues}

Two of the more important design issues facing the laboratory today are concerned with the observed ramp dependence on the quench level of the superconducting dipole magnets, and the vacuum of the Collider beam tube and need for a liner. The dipole magnets for the Collider are required to ramp to full energy at a modest $4 \mathrm{~A} / \mathrm{sec}$. At this rate present built magnets are able to achieve top energy without quenching. However, when ramped at rates corresponding to High Energy Booster operation, which must ramp at rates at least 15 times higher, the magnets are seen to quench at unacceptable currents. The actual quench level depends upon the magnet and appears to be connected to the interstrand resistance of the cable used. This problem must be understood and solved before HEB magnets go into production.

The vacuum/liner $R \& D$ effort has progressed on several fronts. A beam tube liner has been designed and is being tested for heat leak, photodesorption, and will be used in a future string test to investigate behavior under quench forces. Photodesorption experiments at BNL and BINP, Russia, have been initiated which confirm the magnitude of photodesorption on warm electroplated copper tubes first observed by Bintinger, et al.[5] Future test results will include measurements of cold tubes with applied magnetic fields. A Collider vacuum technical meeting is being held simultaneously with this DPF meeting.

\section{References}

1. T. Dombeck, these proceedings.

2. M. J. Syphers, in DPF91, ed. D. Axen et al., World Sci., (1992) 1044.

3. Site-Spec. Concep. Design Rpt. of the SSC, SSCL-SR-1056, 1990.

4. D. A. Edwards and M. J. Syphers, in (SSCL-SR-1213, 1992) 77.

5. D. Bintinger, et al., SSC Report 102. 